Article

\title{
Electronic Commerce for Sustainable Rural Development: Exploring the Factors Influencing BoPs' Entrepreneurial Intention
}

\author{
Lijuan Huang ${ }^{1}$, Guojie Xie ${ }^{1, *(\mathbb{C})}$, Raoyi Huang ${ }^{2}$, Guokai $\mathrm{Li}^{3}$, Weiwei Cai ${ }^{4}\left(\mathbb{D}\right.$ and Chrysostomos Apostolidis ${ }^{5}$ (D) \\ 1 School of Management, Guangzhou University, Guangzhou 510006, China; somhuanglj@gzhu.edu.cn \\ 2 Faculty of Engineering, The Hong Kong Polytechnic University, Hong Kong, China; \\ 18082421d@connect.polyu.hk \\ 3 Department of Civil, Environmental and Architectural Engineering (DICEA), University of Padua, \\ 35131 Padua, Italy; guokai.li@studenti.unipd.it \\ 4 Graduate School, Northern Arizona University, Flagstaff, AZ 86011, USA; wc358@nau.edu \\ 5 Durham University Business School, Durham University, Millhill Ln, Durham DH1 3LB, UK; \\ chrysostomos.apostolidis@durham.ac.uk \\ * Correspondence: 1111965003@e.gzhu.edu.cn
}

Citation: Huang, L.; Xie, G.; Huang, R.; Li, G.; Cai, W.; Apostolidis, C. Electronic Commerce for Sustainable Rural Development: Exploring the Factors Influencing BoPs' Entrepreneurial Intention. Sustainability 2021, 13, 10604. https://doi.org/10.3390/su131910604

Academic Editor: Antonis A. Zorpas

Received: 6 July 2021

Accepted: 21 September 2021

Published: 24 September 2021

Publisher's Note: MDPI stays neutral with regard to jurisdictional claims in published maps and institutional affiliations.

Copyright: (c) 2021 by the authors. Licensee MDPI, Basel, Switzerland. This article is an open access article distributed under the terms and conditions of the Creative Commons Attribution (CC BY) license (https:// creativecommons.org/licenses/by/ $4.0 /)$.

\begin{abstract}
Rural e-commerce entrepreneurship is an effective and credible means to alleviate poverty and promote sustainable social development, particularly in the Base of the Pyramid (BoP). Understanding how to encourage BoPs' entrepreneurial intention in the rural e-commerce market has become a key issue for private enterprises and local governments. Based on the entrepreneurial event model, we constructed a research framework to evaluate the factors influencing BoPs' entrepreneurial intention in rural e-commerce. We conducted an online survey of rural e-commerce practitioners from Jieyang and Chaozhou in Guangdong Province, China, and empirically analyzed the survey results using SmartPLS software. The results show that professional knowledge, resource endowment, information and communication technology, and logistics infrastructure have a significant positive impact on BoP entrepreneurship in rural e-commerce, while previous market channels had a significant negative impact. Based on the findings, we recommend that BoPs should focus more on cultivating professional knowledge in e-commerce entrepreneurship and capitalize on local resource advantage. E-commerce enterprises and local governments should strengthen and improve information communication technology and logistics infrastructure among BoP communities. Policymakers should support BoP entrepreneurship in rural e-commerce by creating a favorable environment.
\end{abstract}

Keywords: rural e-commerce; entrepreneurship; intention; BoP community; factors

\section{Introduction}

Given the emergence of information and communication technology and the growing ubiquity of mobile smartphone applications, e-commerce is no longer limited to cities and is becoming a major driver of sustainable economic development in rural areas [1]. E-commerce giants from China, such as Alibaba, JingDong, and Pinduoduo, are targeting rural markets while also expanding in urban markets. Statistical data show that in March 2021, China had reached 309 million rural internet users, representing 55.9\% internet penetration rate in the country's rural population [2]. China's rural online retail sales reached 1.79 trillion yuan in 2020, up by 8.95 from the previous year [3]. Comprising about $70 \%$ of the national population, rural areas are considered the Bottom of the Pyramid (BoP) region. The BoP generally refers to a community where a low-income population lives on a per capita income of less than $\$ 2$ per day and where the population has limited skills, knowledge, and insufficient financial resources [4]. While these communities have significant low-income and poor populations, they also hold huge market potential [4]. 
The development of rural e-commerce plays a positive role in improving the living standards of the BoP. For example, BoPs can solve the problems of limited options and good scarcity through online shopping [5]. In addition, rural e-commerce has created logisticsrelated jobs for BoP communities, providing many rural residents with the opportunity to work locally instead of emigrating into the city [6]. In the development of rural e-commerce, the BoP plays the roles of consumer (e.g., Lappeman et al. [5]; Campos et al. [7]) and partner (e.g., Wan et al. [8]; Chen and Yu [9]).

However, with the further expansion of rural e-commerce, BoPs are no longer satisfied with simply being consumers and partners, and some rural areas have seen a boom in $\mathrm{BoP}$ entrepreneurship. Some scholars point out that BoPs become consumers and partners mainly from external help [10] and become entrepreneurs due to endogenous factors [11]. Additionally, while the endogenous growth of BoP entrepreneurship is crucial to the resilience and sustainability of BoP communities [12], numerous practical problems and hurdles hinder its progress [6]. One major challenge is how the BoP can cope with the internal and external environment in order to transition from being a consumer or partner to becoming an entrepreneur. As a result, a significant question arises: what factors influence BoPs' entrepreneurial intention to start a rural e-commerce business?

At present, the case analysis method is commonly used to explore this topic (e.g., Liu [6]; Guo and Zhou [10]; Gao and Liu [11]; Zhou et al. [13]), and only a few studies have used empirical analysis (see Mei et al. [14] for a notable exception). We developed a "Desirability-Feasibility" (DF) theoretical model of factors influencing BoPs' intention in rural e-commerce entrepreneurship to address this study gap. The solution to the issue allows us to better understand and identify the factors that influence BoPs' rural e-commerce entrepreneurial intention. Thus, enterprises and local governments may give targeted assistance to low-income people who want to start an e-commerce business. Furthermore, our research can assist BoPs in identifying positive socio-economic aspects and assist them in making the transition to rural e-commerce entrepreneurial growth. This study has enriched the literature on $\mathrm{BoP}$ entrepreneurship in terms of technique and content by empirically evaluating the factors that influence BoPs' rural e-commerce entrepreneurial intention. We validated the research hypotheses in the theoretical model and explored the mediating role of information and communication technology (ICT) and logistics.

The rest of this article is arranged as follows. The literature review and theoretical background are presented in the second section, which also develops the theoretical model and offers the study hypotheses. The third section discusses the research methods and empirical results, while the fourth section presents the theoretical and practical implications. Finally, the fifth section provides the conclusion, limitations, and future research direction.

\section{Research Background and Hypothesis}

\subsection{Literature Review}

\subsubsection{The Rise of BoP Rural E-Commerce Entrepreneurship}

According to existing literature, the BoP market has experienced three development stages [15]: BoP 1.0, wherein enterprises begin to sell their products to the BoP [4]; BoP 2.0, in which the BoP accumulate skills and capabilities of business while enterprises continue selling their products [16]; and BoP 3.0, wherein the BoP is regarded as the backbone of enterprises and becomes an ecosystem of innovation and sustainable development [17]. These development stages are comparable to the development process of rural e-commerce in BoP communities.

In the first phase of development, the BoP mainly acts as consumers in the rural ecommerce market [18]. At this stage, the urban e-commerce market is gradually becoming saturated [18], nudging e-commerce enterprises to expand to untapped BoP markets [19,20]. This expansion offsets the lack of physical stores in many rural communities, providing them with greater access to more products and options [5,21].

In the second phase, BoP becomes a partner in rural e-commerce [8]. Jobs related to e-commerce are generated with the expansion and development into BoP communities [6]. 
In addition, rural e-commerce allows for the extension and growth of some businesses beyond the industrial chain, such as product packaging [22]. These rural e-commerce jobs and businesses are straightforward and can help reduce employment costs in e-commerce enterprises [8].

In the third phase of rural e-commerce development, BoP takes part as entrepreneurs [11]. The BoP no longer relies on external help for development but instead uses an inner-driven approach [10]. In this phase, which generally occurs at the mature development of rural e-commerce, the BoP is able to start a business independently through internal and external learning [14].

At present, many underdeveloped areas in China have reached the third stage of rural e-commerce in development, and the entrepreneurial atmosphere of BoP is strong [6,10,11]. However, specific factors that could potentially affect the implementation and progress of rural e-commerce entrepreneurship have not been thoroughly explored and investigated $[10,14]$. Empirical assessments and independent evaluations are important to better understand these internal and external variables affecting rural e-commerce.

\subsubsection{Influencing Factors of BoP in Rural E-Commerce Entrepreneurship}

Numerous findings and conclusions regarding the factors affecting BoP's rural ecommerce entrepreneurship have been made through case studies. For example, Liu [6] and Gao and Liu [11] concluded that start-up costs, internet use, start-up seeds, and professional knowledge (which then evolve into entrepreneurial ability) are important factors impacting rural e-commerce entrepreneurship. Zhou et al. [13] and Zheng et al. [23] highlighted the promoting role of ICT in BoP rural e-commerce entrepreneurship. Chen and $\mathrm{Yu}$ [9] found that the development prospects of rural e-commerce and improvements in urban and rural logistics infrastructure promote rural e-commerce entrepreneurship in BoP. Guo and Zhou [10] concluded that emerging digital technology and entrepreneurial ability are key factors that support $\mathrm{BoP}$ in carrying out rural e-commerce entrepreneurship. Liang et al. [24] found that government support plays a promoting role in creating entrepreneurial conditions for BoP, enhancing entrepreneurial ability, stimulating entrepreneurial motivation, and supporting entrepreneurial activities.

Few studies have employed empirical analysis in exploring rural e-commerce entrepreneurship. For instance, Mei et al. [14] concluded that entrepreneurial agglomeration, local resource endowment, entrepreneurial atmosphere and culture, entrepreneurial threshold, exemplary leadership, and government support positively impact BoP rural entrepreneurship. Table 1 summarizes the various studies on factors affecting BoP in rural e-commerce entrepreneurship.

Table 1. Factors influencing BoP carry out rural e-commerce entrepreneurship.

\begin{tabular}{ccc}
\hline No. & Motivations/Influence Factors & References \\
\hline 1 & $\begin{array}{c}\text { Start-up cost, entrepreneurial seeds } \\
\text { Professional knowledge, } \\
\text { entrepreneurial ability }\end{array}$ & $\begin{array}{c}\text { Liu [6]; Gao and Liu [11] } \\
\text { Liu [6]; Guo and Zhou [10]; Gao } \\
\text { and Liu [11] }\end{array}$ \\
3 & ICT & $\begin{array}{c}\text { Liu [6]; Guo and Zhou [10]; Gao } \\
\text { and Liu [11]; Zhou et al. [13]; Zheng } \\
\text { et al. [23] }\end{array}$ \\
4 & $\begin{array}{c}\text { Logistics infrastructure, the } \\
\text { development prospect of rural } \\
\text { e-commerce }\end{array}$ & $\begin{array}{c}\text { Chen and Yu [9] } \\
\text { Government support } \\
6\end{array}$ \\
7 & $\begin{array}{c}\text { Resource endowment } \\
\text { Entrepreneurial atmosphere and } \\
\text { culture, entrepreneurial threshold }\end{array}$ & $\begin{array}{c}\text { Liang et al. [24]; Mei et al. [14] } \\
\text { Mei et al. [14] }\end{array}$ \\
\hline
\end{tabular}


These studies can be used as references for further analyses of rural BoP markets and e-commerce entrepreneurship. However, most of these studies use case studies and are not evaluated using empirical tests. The case study method (especially the single case method) may limit the generalizability of research results [25]. Therefore, more empirical research methods are needed for confirmation and verification, which is conducive to generalizing the research results to more situations [25]. Especially from the perspective of BoP, it remains unclear how they view the influence of various factors. To address the current research gap, this study used the entrepreneurial event model (desirability, feasibility aspects) in identifying and analyzing the factors influencing BoPs' entrepreneurial intention in rural e-commerce.

\subsection{Theoretical Model}

\subsubsection{The Entrepreneurial Event Model}

Shapero and Sokol [26] proposed the entrepreneurial event model, which is used to describe and quantify entrepreneurial intention. They believe that considering of entrepreneurship as an "entrepreneurial event" rather than a social aspect makes more sense. That is, a variety of variables and factors affect the entrepreneurial event. In the meantime, Shapero and Sokol [26] argued that the exact action performed in an entrepreneurial event is influenced by perceived desirability (values) and feasibility. Perceived desirability relates to how appealing the prospect of entrepreneurship is to a person, while perceived feasibility refers to how confident a person is in their capability to start a business [26,27].

Scholars (e.g., Krueger [27]) have confirmed the entrepreneurial event model throughout time, and it has been extensively utilized in entrepreneurship study as a scientific research paradigm. Soomro et al. [28], for example, used the entrepreneurial event model to study the entrepreneurial intent of business students in public institutions in Pakistan. Ali et al. [29] used the entrepreneurial event model to investigate the elements that influence Thai college students' entrepreneurial intentions. The entrepreneurial event model (desirability, feasibility elements) was utilized as the theoretical framework in this study to investigate the various factors influencing BoPs' entrepreneurial intention in rural e-commerce.

\subsubsection{Research Model Construction}

Based on the entrepreneurial event model, we divided the factors influencing BoPs' entrepreneurial intention in e-commerce into two types: desirability and feasibility. The development prospect of rural e-commerce is a feasible parameter for the factors of desirability, according to available literature. In addition, according to research by Karnani [30] and Guo and Zhou [10], two additional desirability factors were used: previous income and previous market channels.

For the factors of feasibility, based on existing literature, possible parameters include start-up costs, entrepreneurial seed, professional knowledge, entrepreneurial ability, resource endowment, entrepreneurial atmosphere and culture, entrepreneurial thresholds, information and communication technology (ICT), logistics infrastructure, and government support. For Liu [6] and Gao and Liu [11], entrepreneurial seeds, atmosphere, and culture can significantly influence and encourage BoPs to increase their professional knowledge and boost their entrepreneurial abilities. These studies suggest that the enhancement of BoP's entrepreneurial abilities is mainly dependent on increasing professional knowledge. Meanwhile, Xing et al. [31] concluded that the BoP market could be entered at any time and that the threshold for rural e-commerce entrepreneurship is low [14]. Liang et al. [24] had concluded that government support ultimately influences BoP's entrepreneurial abilities, motivation, and activities. Based on their recommendations, we excluded the threshold factor and other overlapping parameters. Start-up costs, professional knowledge, resource endowments, ICT, and logistics infrastructure are the final feasibility factors considered in this study. In addition, we hypothesized that ICT and logistics infrastructure affect the start-up costs of BoP [6,9] and that ICT affects the professional knowledge of BoPs [6]. 
Based on the above discussion, we developed a theoretical research model, as shown in Figure 1.

\section{Types of factors}

Factors

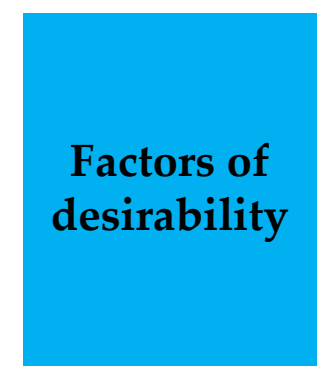

Factors of feasibility

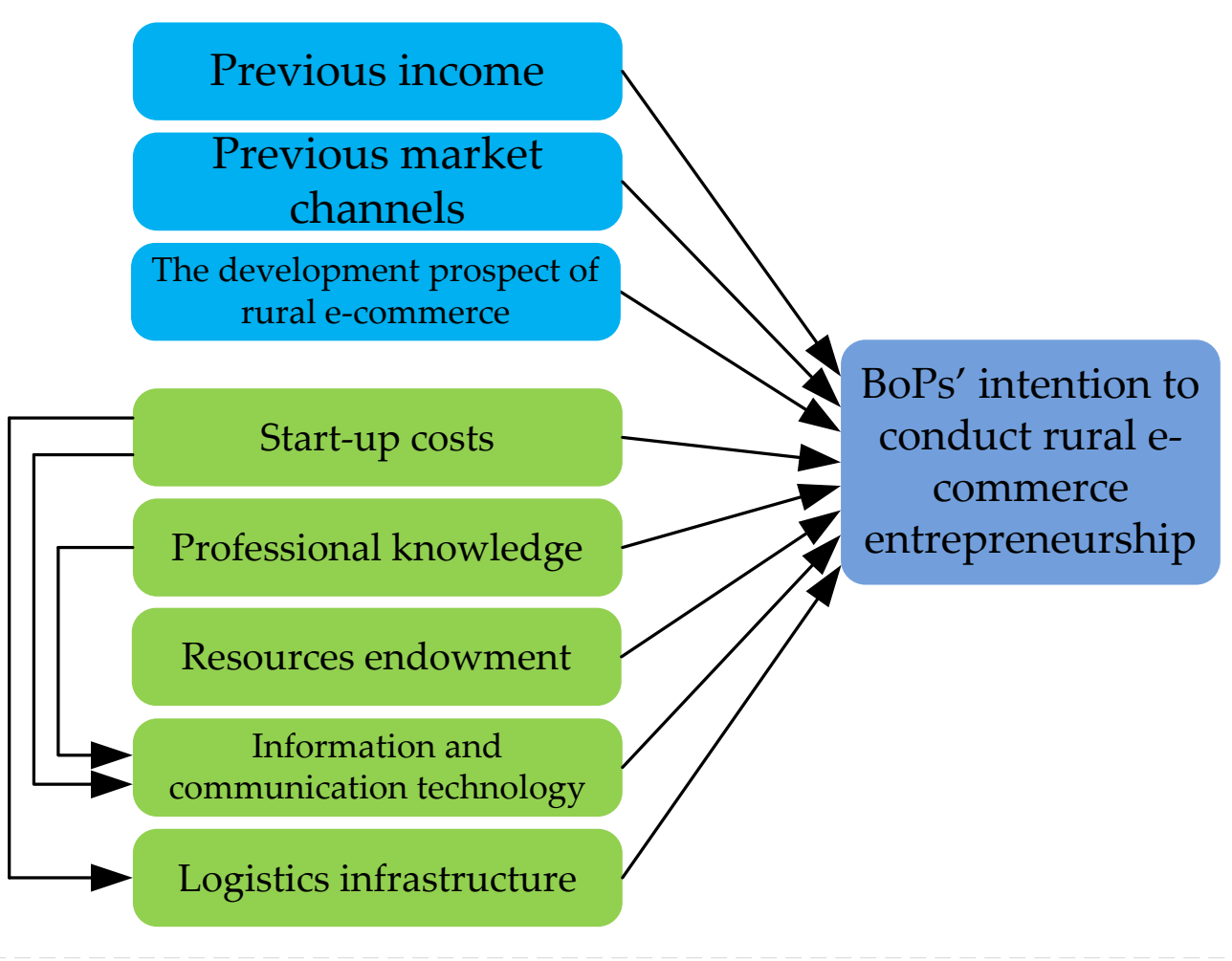

Figure 1. Theoretical research model.

\subsection{Hypothesis}

Using the study's theoretical research model, we propose a number of research hypotheses in terms of desirability and feasibility factors.

\subsubsection{Factors of Desirability}

The attractive elements that might change the unfavorable status quo are referred to as desirability factors. These factors encourage BoPs to improve their previous adverse condition, and many see rural e-commerce business as a promising opportunity. Previous income, previous market channels, and the development prospect of rural e-commerce are all desirable factors in this study.

(1) Previous income

According to Prahalad [4], BoP commonly suffers from severe income shortage. The serious lack of income in BoP causes greater harm than the lack of goods and services in these communities [30]. While also obtaining external help, many BoP communities actively help themselves to improve their situations using their own abilities [10]. Forced by the lack of income, BoP communities actively seize possible opportunities, such as becoming entrepreneurs in the rural e-commerce market [6]. The study of Bruton et al. [32] found that one avenue used by the BoP to alleviate poverty is entrepreneurship. Based on these arguments, we propose the following hypothesis:

Hypothesis 1 (H1). The lower the previous income of the BoP, the stronger the intention to become entrepreneurs in the rural e-commerce market. 
(2) Previous market channels

The emergence of e-commerce and the spread of the platform economy have reduced the need for middlemen, providing BoP with a variety of online sales channels $[6,33]$. For example, e-commerce giants like Alibaba, Jingdong, and Pinduoduo have developed rural e-commerce businesses to improve trading in BoP communities, resulting in the transformation and upgrading of rural economies [34]. BoP communities are mostly in remote areas, where the local market capacity is limited and the exporting of products can be challenging [4]. The introduction and expansion of rural e-commerce can help solve issues in product exports. Therefore, we propose the following hypothesis:

Hypothesis 2 (H2). The narrower the previous market channels of the BoP community, the stronger their intention to become entrepreneurs in rural e-commerce.

(3) The development prospect of rural e-commerce

As urban e-commerce markets get nearly saturated, more and more enterprises expand to BoP areas for new markets [18]. BoP communities not only contain huge market potential [31] but may also have high productivity and creativity to be tapped. After the first stage of rural e-commerce development, many BoPs transition from simply being consumers into collaborators [8] or even entrepreneurs $[6,10,11]$, with the hope of improving their income levels and changing their lives [1]. In addition, according to the Ministry of Commerce of China [35], online retail sales in rural areas have increased from 180 billion yuan in 2014 to 1.7 trillion yuan in 2019, with an overall expansion of 8.4 times. By November 2020, China has added nearly 100,000 agricultural and related e-commerce enterprises for the year, more than the total for 2016-2019, indicating broad development prospects for rural e-commerce. Accordingly, we propose the following hypothesis:

Hypothesis 3 (H3). The good development prospect of rural e-commerce is positively correlated with the BoPs' entrepreneurial intention in rural e-commerce.

\subsubsection{Factors of Feasibility}

The parameters related to one feeling that they are personally capable of beginning a firm are referred to as feasibility factors. Start-up costs, professional knowledge, resource endowments, ICT, and logistics infrastructure are all considered feasibility factors in this study.

(1) Start-up costs

A BoP has to consider the start-up cost when starting a rural e-commerce business. These costs include monetary and non-monetary expenses. For example, a BoP needs to buy a computer and a smartphone and connect to the internet. In addition, business transactions and inventories also generate added expenditures [6,8]. Non-monetary expenditures include the time spent acquiring entrepreneurial knowledge and human resources inputs [11]. According to Liu [6], Gao and Liu [11], a cheap cost is all that is required for a BoP to engage in rural e-commerce entrepreneurship, and this is an appealing feature. However, we believe that if start-up costs are excessively high, the BoP may be discouraged from engaging in rural entrepreneurship. Based on these arguments, we propose the following hypothesis:

Hypothesis 4 (H4). The higher the start-up cost, the less likely the BoP would have the intention to engage in rural e-commerce entrepreneurship.

(2) Professional knowledge

The BoP has limited skills, knowledge, and financial resources [4]. Therefore, if BoPs want to engage in entrepreneurial activities, they must enhance their entrepreneurial skills [11]. BoPs can increase their entrepreneurial knowledge and skills in rural e-commerce through online and offline activities [6]. In addition, mentoring with local entrepreneurial 
leaders can increase competencies in information technology, online shopping [8], selfmarketing, design, production, and business operations [6]. Ultimately, enhanced BoP expertise improves entrepreneurial capabilities $[6,10,11]$. Accordingly, we propose the following hypothesis:

Hypothesis $\mathbf{5}$ (H5). The more professional knowledge the BoPs master, the stronger their intention to become entrepreneurs in rural e-commerce.

(3) Resource endowments

Resource endowment refers to the unique resources that enterprises can obtain locally, including landscape, material resources, community resources, heritage, and cultural symbols [36]. Generally speaking, starting a business based on local resource endowment provides entrepreneurs with a certain competitive advantage in the local market [37]. Local resource endowment can significantly affect entrepreneurial behavior [14]. For example, in areas with rich, unique natural sceneries, BoPs can consider engaging in tourism-related activities. In regions with unique agricultural products, BoPs can move into entrepreneurial activities related to production and sales. Therefore, we propose the following hypothesis:

Hypothesis 6 (H6). The richer the local resource endowment, the stronger the intention of BoP towards rural e-commerce entrepreneurship.

(4) ICT

The development of ICT and e-commerce platforms provides important entrepreneurial support for the BoP in rural e-commerce $[13,23]$. The widespread use of ICT has narrowed the distance between rural and urban areas, allowing transactions to be conducted online quickly and easily. More importantly, it alleviates (or even eliminates) BoP disadvantages in terms of information asymmetry and market imbalance [6]. With the use of the internet, $\mathrm{BoP}$ can obtain more market information, conduct online learning, and carry out diversified online marketing. Accordingly, we propose the following hypothesis:

Hypothesis 7 (H7). The development of ICT is positively correlated with the intention of BoP to become entrepreneurs in rural e-commerce.

(5) Logistics infrastructure

Rural areas are generally characterized by low population density [18], making logistics infrastructure particularly important. As fundamental facilities for rural e-commerce development, transportation and logistics infrastructures are crucial in production, packaging, sales, and after-sales [38]. Due to their remoteness, many rural areas have relatively poor logistics infrastructure. In recent years, logistics facilities in many rural areas have gradually improved due to the rural strategy of the e-commerce giants [39]. Improvements in the logistics infrastructure in rural areas can help provide a more conducive environment for rural e-commerce entrepreneurship [9]. Based on these arguments, we propose the following hypothesis:

Hypothesis 8 (H8). The improvement of logistics infrastructure is positively correlated with BoPs' entrepreneurial intention in rural e-commerce.

\subsubsection{Mediating Effect}

(1) The mediating effect of ICT

According to Liu [6], Gao and Liu [11], and Zhou et al. [13], the wide application of ICT in BoP communities can reduce start-up costs (e.g., transaction cost reduction) and promote learning and acquisition of professional knowledge. Therefore, the following research hypotheses are proposed: 
Hypothesis 9 (H9). The wider the application of ICT in BoP, the lower the costs for BoP in rural e-commerce entrepreneurship.

Hypothesis 10 (H10). The wider the application of ICT in BoP, the more conducive it would be for BoP to acquire professional knowledge in rural e-commerce entrepreneurship.

(2) The mediating effect of logistics infrastructure

Improvements in logistics infrastructure may reduce start-up costs for BoP [9]. For example, competition among multiple logistics service providers can reduce prices for various services and prevent monopolies. It can also encourage enterprises to improve their delivery speeds and expand their delivery range. These effects can encourage and support BoP entrepreneurs in the rural e-commerce market. Accordingly, we propose the following hypothesis:

Hypothesis 11 (H11). The better the logistics infrastructure, the lower the costs for BoP to engage in rural e-commerce entrepreneurship.

\section{Research Methodology and Results}

This study explores the factors affecting BoP entrepreneurship in rural e-commerce. Based on the research theoretical model and hypotheses, we formulated the specific research processes, as shown in Figure 2.

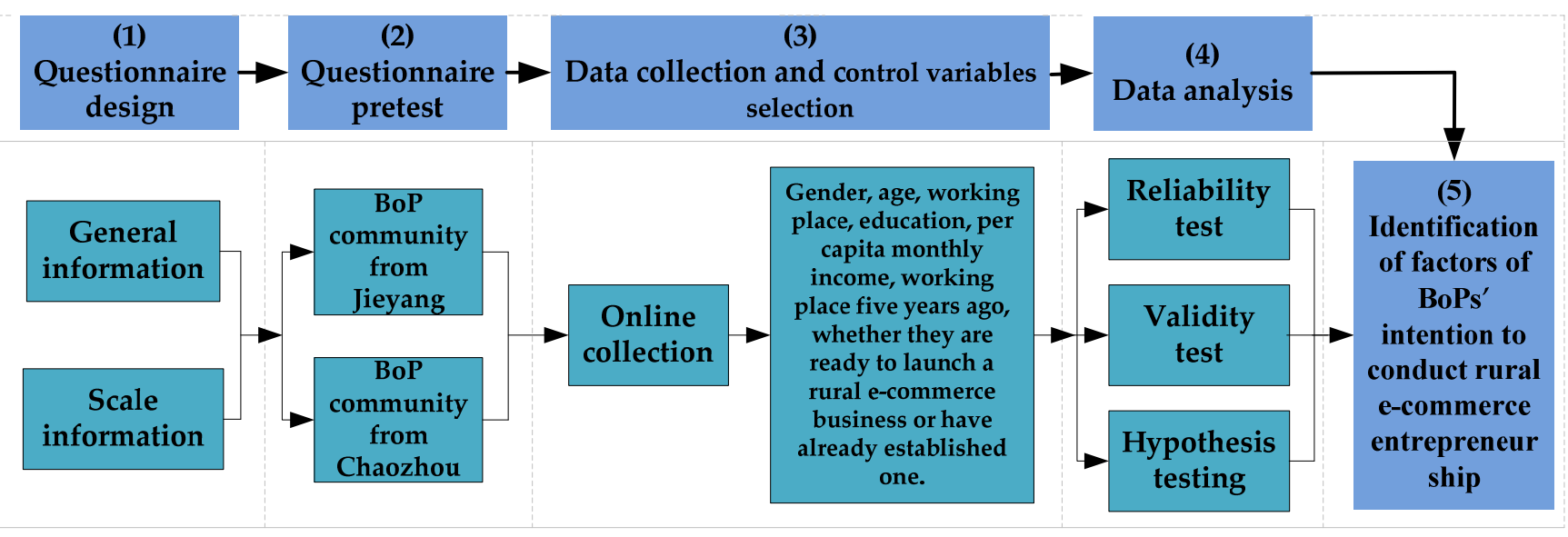

Figure 2. The specific process of the study.

\subsection{Questionnaire Design}

The questionnaire consists of two parts: the respondent information and the measurement scale for each latent variable. In the respondent information section, the respondents were asked for their gender, age, workplace, education level, per capita monthly household income before engaging in entrepreneurship, workplace five years ago, and whether they are ready to launch a rural e-commerce business or have already established one. For the measurement scale, nine latent variables were used. Among the observed latent variables, a 5-point Likert scale was used to quantify the respondent's level of agreement: (1) strongly disagree, (2) disagree, (3) neither agree nor disagree, (4) agree, and (5) strongly agree [40,41]. Observation variables were set based on the conclusions and recommendations from previous studies, as summarized in Table 2. 
Table 2. Item of constructs in the proposed model.

\begin{tabular}{|c|c|c|}
\hline Latent Variables & Observable Variables & References \\
\hline Previous income (PI) & $\begin{array}{l}\text { 1a: I had a relatively low income before starting my own business. } \\
\text { 1b: I think starting a business in rural e-commerce is a good way to get rid of } \\
\text { poverty. } \\
\text { 1c: I hope to change the current economic situation by starting my own } \\
\text { business in rural e-commerce. }\end{array}$ & $\begin{array}{l}\text { Karnani [30]; Guo and } \\
\text { Zhou [10]; } \\
\text { Bruton et al. [32] }\end{array}$ \\
\hline $\begin{array}{l}\text { Previous market } \\
\text { channel (PMC) }\end{array}$ & $\begin{array}{l}\text { 2a: I think the rural market capacity is limited; it is difficult to meet the needs } \\
\text { of sales. } \\
2 \mathrm{~b} \text { : Before rural e-commerce entered, the problem of unsalable agricultural and } \\
\text { sideline products often appeared. } \\
\text { 2c: I hope to enhance the sales of products through the development of rural } \\
\text { e-commerce. }\end{array}$ & $\begin{array}{l}\text { Prahalad [4]; Liu [6]; } \\
\text { Wang et al. [33] }\end{array}$ \\
\hline $\begin{array}{l}\text { The development } \\
\text { prospect of rural } \\
\text { e-commerce (DPRE) }\end{array}$ & $\begin{array}{l}\text { 3a: I firmly believe that rural e-commerce has broad prospects for } \\
\text { development. } \\
\text { 3b: I think starting a business in rural areas can bring about changes in income } \\
\text { and life. } \\
\text { 3c: I am optimistic about the future of the rural e-commerce market and want } \\
\text { to become a rural e-commerce entrepreneur. }\end{array}$ & $\begin{array}{c}\text { Chao et al. [1]; Sousa } \\
\text { et al. [18] }\end{array}$ \\
\hline Start-up costs (SuC) & $\begin{array}{l}\text { 4a: Entrepreneurship of rural e-commerce requires high capital investment. } \\
\text { 4b: I need to spend more time on rural e-commerce entrepreneurship. } \\
\text { 4c: I need to spend more energy on rural e-commerce entrepreneurship. }\end{array}$ & $\begin{array}{l}\text { Liu [6]; Wan et al. [8]; } \\
\text { Gao and Liu [11] }\end{array}$ \\
\hline $\begin{array}{c}\text { Professional } \\
\text { knowledge (PK) }\end{array}$ & $\begin{array}{l}\text { 5a: I think it is very important to obtain professional knowledge to carry out } \\
\text { rural e-commerce entrepreneurship. } \\
\text { 5b: I am keen on obtaining professional knowledge of rural e-commerce } \\
\text { entrepreneurship through online or offline means. } \\
\text { 5c: I can better obtain and master the professional knowledge of rural } \\
\text { e-commerce entrepreneurship. }\end{array}$ & $\begin{array}{l}\text { Liu [6]; Wan et al. [8]; } \\
\text { Guo and Zhou [10]; } \\
\text { Gao and Liu [11] }\end{array}$ \\
\hline
\end{tabular}
e-commerce entrepreneurship.

6a: I think the local characteristic resources are conducive to my rural e-commerce business.

Resources endowment $\quad 6 \mathrm{~b}$ : In my opinion, the local characteristic resources will enable me to maintain (RE) a certain competitive advantage in the process of starting a rural e-commerce business.

Borch et al. [37]; Mei 6c: I often think about how to start a rural e-commerce business based on local et al. [14] characteristic resources.

7a: I think access to information and communication technology has made my business easier.

Information and communication technology (ICT) 7b: I think access to information and communication technology has helped me get more market information.

7c: I think access to information and communication technology has provided

Liu [6]; Zhou et al. [13]; Zheng et al. [23] me with a variety of marketing tools.

8a: Our local logistics infrastructure is gradually improving.

8b: I think the improvement of logistics infrastructure facilitates our production and sales.

8c: In my opinion, the improvement of logistics infrastructure will guarantee the development of rural e-commerce business.

a: I want to start a rural e-commerce business.

Entrepreneurial intention (EI) b: Starting a rural e-commerce business has always been what I have wanted to do.

c: I will try to take steps to start a rural e-commerce business.

Zhou and Liu [38];

Zhang et al. [39]; Chen and $\mathrm{Yu}[9]$

Liu [6];

Gao and Liu [11];

Kautonen et al. [42]

\subsection{Questionnaire Pretest}

In order to ensure the validity and reliability of the questionnaire, we conducted a pretest before the formal survey. First, we sent the designed questionnaire to two senior scholars in the field, asking them to evaluate the logic, semantics, items, and other aspects of the questionnaire. According to their feedback, we made the first round of revisions to 
the questionnaire. Then, we randomly found four rural e-commerce entrepreneurs ( 2 each in the BoP community from Puning and Chaozhou) to carry out the questionnaire pretest through the online method. After the pretest, we had a brief online conversation with them and asked for their opinions on their completed questionnaire. We found that all four subjects could complete the questionnaire within $8 \mathrm{~min}$, and they were relatively satisfied with the setting of the questionnaire items. Additionally, according to their feedback, we defined and explained "resource endowment" at the beginning of the questionnaire to help respondents better understand the questionnaire's content.

\subsection{Data Collection and Control Variables Selection}

The data used in this study were from rural e-commerce entrepreneurs and those planning to start rural e-commerce enterprises in BoP communities in Jieyang and Chaozhou, located in the eastern part of Guangdong Province (see Figure 3). Jieyang and Chaozhou are far away from the developed region of the Pearl River Delta and belong to the underdeveloped region of the province [43]. In 2017, Guangdong published a list of relatively poor villages, in which Jieyang had 162 and Chaozhou had 45 [44]. With the growth of rural e-commerce in recent years, BoPs in Jieyang and Puning have adapted to recent economic trends, implementing rural e-commerce activities and strengthening the local entrepreneurial atmosphere.

\section{The area where the data were collected.}
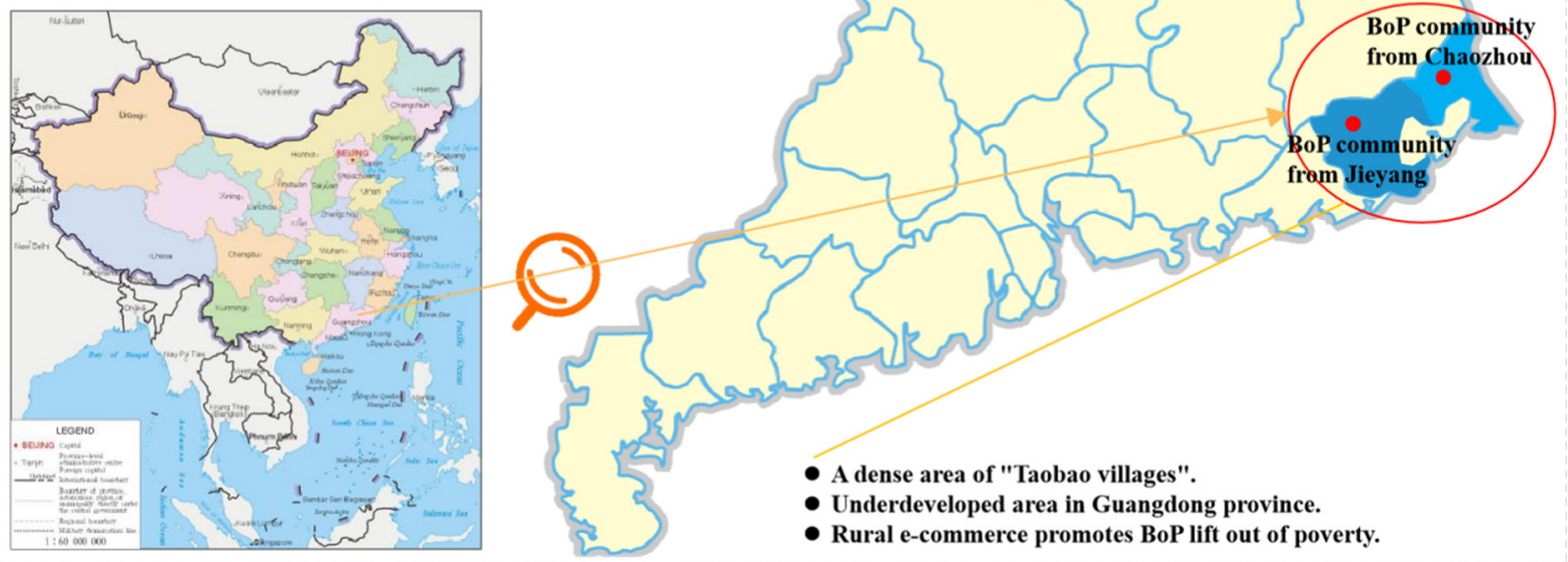

Figure 3. Data collection area.

One way to gauge the level of e-commerce penetration for a city or town is through the number of Taobao Villages present in the area. To be considered a Taobao Village, three conditions must be met [45]: (1) Business site: in rural areas, the administrative village as a unit; (2) Sales scale: the annual sales of e-commerce on the Alibaba platform reaches 10 million yuan; (3) Online enterprises scale: the number of active online stores in the village reaches 100 , or the number of active online stores reaches $10 \%$ of the number of households. According to the Alibaba Institute, in 2020, Jieyang had 121 Taobao villages, while Chaozhou had 122 [46]. Among them, the number of Taobao villages in Chaoan, Chaozhou and Puning, Jieyang were in the top 15 nationally [47].

Boosted by the expansion of rural e-commerce, poor villages in Jieyang and Chaozhou were lifted out of poverty in 2019 [48,49]. Puning Village in Jieyang was awarded the title of "National Comprehensive Demonstration County of E-commerce into Rural Areas" 
in 2019 [50]. Given the outstanding performance of these areas in rural e-commerce entrepreneurship and poverty alleviation, we choose them as the study site.

Due to COVID-19 protocols and restrictions, the survey was conducted fully online. Three methods were used to collect the questionnaires. First, electronic questionnaires were sent via WeChat Moments to BoPs engaged in rural e-commerce entrepreneurship. Second, e-questionnaires were sent to target groups through local rural e-commerce associations. Third, since our team has had more than ten years of experience studying rural e-commerce entrepreneurship in Guangdong, we surveyed some of our previously established BoP contacts engaged in rural e-commerce entrepreneurship.

The survey was conducted in June 2021. It was an academic and public welfare survey, and the respondents received no monetary compensation. Because all of the questionnaires were delivered online, they were sent through WeChat Moments, WeChat Groups (created by local rural e-commerce associations, with the bulk of the members being rural e-commerce practitioners), and other platforms. Therefore, the entire investigation process was accessible at any moment, and the number of participants $(n)$ is flexible. It is worth mentioning that the questionnaire includes certain criteria for identifying potential respondents. The first is whether they are working in rural e-commerce in Jieyang or Chaozhou, and the second is whether they are preparing to establish a rural e-commerce firm or have already started one. After screening, 172 of the 216 questionnaires we gathered were found to be legitimate, giving us a success rate of $79.63 \%$. Table 3 summarizes the descriptive statistical results.

Table 3. Descriptive statistical results of valid sample.

\begin{tabular}{|c|c|c|c|c|c|}
\hline Category & Item & Ratio & Category & Item & Ratio \\
\hline \multirow{3}{*}{ Gender } & Male & $39 \%$ & \multirow{2}{*}{ Workplace } & Jieyang & $56 \%$ \\
\hline & Female & $61 \%$ & & Chaozhou & $44 \%$ \\
\hline & $18-25$ & $17 \%$ & \multirow{4}{*}{$\begin{array}{l}\text { Per capita monthly income of the family before starting } \\
\text { the business }\end{array}$} & $\leq 2000$ yuan & $16 \%$ \\
\hline \multirow{3}{*}{ Age } & $26-35$ & $35 \%$ & & $2001-3000$ yuan & $23 \%$ \\
\hline & $36-45$ & $38 \%$ & & $3001-4000$ yuan & $52 \%$ \\
\hline & $>45$ & $10 \%$ & & $>4000$ yuan & $9 \%$ \\
\hline \multirow{4}{*}{ Education level } & $\leq$ Middle school & $47 \%$ & \multirow{2}{*}{ Workplace five years ago } & Urban & $43 \%$ \\
\hline & High school & $26 \%$ & & Rural & $57 \%$ \\
\hline & Junior college & $14 \%$ & Whether they are ready to launch a rural e-commerce & Yes & $100 \%$ \\
\hline & $\geq$ Bachelors & $13 \%$ & business or have already established one & No & $0 \%$ \\
\hline
\end{tabular}

To minimize the impact of extraneous variables on the research results [41], the following parameters were set as control variables: respondents' gender, age, education level, location, family per capita monthly income before starting the business, workplace five years ago, and whether they are ready to launch a rural e-commerce business or have already established one. The respondents in our valid sample for the last control variable are divided into two groups. The first group consists of BoPs who are planning to establish rural e-commerce enterprises, while the second group comprises of BoPs who have already launched rural e-commerce operations. Even for BoPs that have built rural e-commerce enterprises, we believe that several factors in the planning stage (before carrying out rural e-commerce business) might influence their entrepreneurial intention. As the entrepreneurial intention comes before the entrepreneurial behavior [42], BoPs that operate rural e-commerce enterprises need to respond to the questionnaire in a recall way. In Table 3, the statistical results show that the majority of the respondents were women (61\%), between the ages of 26 and 45 (73\%), and with relatively low education levels (73\% without a college degree).

\subsection{Data Analysis}

Using the SmartPLS software, we constructed the data analysis model and conducted the empirical analysis. The data analysis model is based on the structural equation model (SEM), which can analyze independent and dependent variables at various stages and integrate measured and assumed causal paths into a simultaneous assessment [51]. Specifically, we used the PLS-SEM method for data analysis, which allows the estimation of 
very complex models with many structural and indicator variables [52]. In addition, the PLS-SEM has great flexibility in the specification of data requirements and relationships between structures and indicator variables [52,53].

PLS-SEM has been widely used in behavioral science and social science research [52]. For example, Munerah [54] applied this method to empirically analyze the factors influencing the willingness of non-green consumers to buy green beauty products. Boubker [55] used this method to empirically analyze the influencing factors of Moroccan students' intentions for entrepreneurship education. These studies show that PLS-SEM is suitable for empirical analysis.

\subsubsection{Reliability and Validity Test}

We tested the reliability and validity of the scale and model, and the results are shown in Table 4. The calculated Cronbach's alpha (CA) (>0.7), composite reliability (CR) $(>0.7)$, and Average Variance Extracted (AVE) $(>0.7)$ all meet the value requirements. The values of the outer loading for the observed variables (see Figure A1 in the Appendix A) were all greater than 0.7 (with a minimum of 0.715) [56]. In addition, the value of the square root of AVE was greater than the correlation coefficient between AVE and other potential variables (see Table 5), indicating that the discriminant validity of the research model is very good and that there is no multicollinearity among the latent variables [56].

Table 4. Results of reliability and validity tests.

\begin{tabular}{cccc}
\hline Construct & CA & CR & AVE \\
\hline PI & 0.718 & 0.841 & 0.639 \\
PMC & 0.856 & 0.912 & 0.777 \\
DPRE & 0.924 & 0.937 & 0.834 \\
SuC & 0.939 & 0.958 & 0.885 \\
PK & 0.705 & 0.836 & 0.630 \\
RE & 0.717 & 0.842 & 0.641 \\
ICT & 0.928 & 0.952 & 0.868 \\
LI & 0.740 & 0.852 & 0.658 \\
EI & 0.840 & 0.903 & 0.757 \\
\hline
\end{tabular}

Note: previous income (PI), previous market channel (PMC), the development prospect of rural e-commerce (DPRE), start-up costs (SuC), professional knowledge (PK), resources endowment (RE), information and communication technology (ICT), logistics infrastructure (LI), entrepreneurial intention (EI).

Table 5. Average Variance Extracted (AVE) square root and factor correlation coefficient.

\begin{tabular}{cccccccccc}
\hline & $\mathbf{H}$ & $\mathbf{H 1}$ & $\mathbf{H 2}$ & $\mathbf{H 3}$ & $\mathbf{H 4}$ & H5 & H6 & H7 & H8 \\
\hline EI & $\mathbf{0 . 8 7 0}$ & & & & & & & & \\
PI & 0.410 & $\mathbf{0 . 7 9 9}$ & & & & & & & \\
PMC & -0.329 & -0.173 & $\mathbf{0 . 8 8 1}$ & & & & & & \\
DPRE & -0.062 & -0.051 & 0.018 & $\mathbf{0 . 9 1 3}$ & & & & & \\
SuC & 0.072 & -0.007 & 0.085 & -0.025 & $\mathbf{0 . 9 4 1}$ & & & & \\
PK & 0.607 & 0.368 & -0.125 & -0.060 & 0.093 & $\mathbf{0 . 7 9 4}$ & & & \\
RE & 0.607 & 0.408 & -0.243 & -0.075 & 0.115 & 0.618 & $\mathbf{0 . 8 0 0}$ & & \\
ICT & 0.158 & 0.023 & -0.013 & -0.055 & 0.034 & 0.049 & 0.083 & $\mathbf{0 . 9 3 2}$ & \\
LI & 0.622 & 0.397 & -0.162 & -0.075 & 0.061 & 0.643 & 0.571 & -0.016 & $\mathbf{0 . 8 1 1}$ \\
\hline Note: diagonal elements are the square root of Average Variance Extracted (AVE).
\end{tabular}

To minimize the influence of common method bias (CMB) [57], we used the method of program control and statistical control test [58]. We first conducted a pretest before the formal survey to ensure questionnaire comprehensibility. All respondents were then informed that participation would be kept anonymous and confidential and that all the data would be used only for academic research. We then used Harman's single factor test to perform exploratory factor analysis on all latent variables [58]. The test results (see Table 6) show that no single factor explained most of the variability $(>40 \%)$, which suggests that the common method bias is not a major concern in the study. 
Table 6. Total variance explained.

\begin{tabular}{ccccccc}
\hline \multirow{2}{*}{ Component } & \multicolumn{3}{c}{ Total } & \multicolumn{2}{c}{ Initial Eigenvalues } & \multicolumn{3}{c}{ Extraction Sums of Squared Loadings } \\
\% of Variance & Cumulative \% & Total & of Variance & Cumulative \% \\
\hline 1 & 6.581 & 24.372 & 24.372 & 6.581 & 24.372 & 24.372 \\
2 & 2.900 & 10.742 & 35.115 & 2.900 & 10.742 & 35.115 \\
3 & 2.701 & 10.003 & 45.118 & 2.701 & 10.003 & 45.118 \\
4 & 2.592 & 9.599 & 54.717 & 2.592 & 9.599 & 54.717 \\
5 & 2.064 & 7.645 & 62.362 & 2.064 & 7.645 & 62.362 \\
6 & 1.466 & 5.429 & 67.791 & 1.466 & 5.429 & 7.791 \\
7 & 1.111 & 4.117 & 71.908 & 1.111 & 4.117 & 71.908 \\
8 & 0.925 & 3.424 & 75.332 & & & \\
\hline
\end{tabular}

\subsubsection{Hypothesis Testing}

The data analysis model was then used to test the research hypotheses (see Figure A1 in the Appendix A). The results show that the $R^{2}$ (R-squared) value of the model was 0.565 , indicating that the model has good explanatory capacity [56]. In addition, the results in Table 7 show that hypotheses $\mathrm{H} 2, \mathrm{H} 5, \mathrm{H} 6, \mathrm{H} 7$, and $\mathrm{H} 8$ passed the hypothesis test ( $p$-value $\leq 0.05$ [56]), while H1, H3, H4, H9, H10, and H11 were not confirmed $(p$-value $>0.05[56])$.

Table 7. Results of hypotheses testing.

\begin{tabular}{cccccc}
\hline Hypothesis & Path & $\begin{array}{c}\text { Path } \\
\text { Coefficient }\end{array}$ & $\boldsymbol{t}$-Value & $\boldsymbol{p}$-Value & $\begin{array}{c}\text { Hypothesis } \\
\text { Supported? }\end{array}$ \\
\hline $\mathrm{H} 1$ & $\mathrm{PI} \rightarrow \mathrm{EI}$ & 0.091 & 1.468 & 0.143 & $\mathrm{~N}$ \\
$\mathrm{H} 2$ & $\mathrm{PMC} \rightarrow \mathrm{EI}$ & -0.188 & 3.333 & 0.001 & $\mathrm{Y}$ \\
$\mathrm{H} 3$ & $\mathrm{DPRE} \rightarrow \mathrm{EI}$ & 0.004 & 0.073 & 0.942 & $\mathrm{~N}$ \\
$\mathrm{H} 4$ & $\mathrm{SuC} \rightarrow \mathrm{EI}$ & 0.021 & 0.421 & 0.674 & $\mathrm{~N}$ \\
$\mathrm{H} 5$ & $\mathrm{PK} \rightarrow \mathrm{EI}$ & 0.228 & 2.750 & 0.006 & $\mathrm{Y}$ \\
$\mathrm{H} 6$ & $\mathrm{RE} \rightarrow \mathrm{EI}$ & 0.203 & 2.340 & 0.020 & $\mathrm{Y}$ \\
$\mathrm{H} 7$ & $\mathrm{ICT} \rightarrow \mathrm{EI}$ & 0.129 & 2.069 & 0.039 & $\mathrm{Y}$ \\
$\mathrm{H} 8$ & $\mathrm{LI} \rightarrow \mathrm{EI}$ & 0.294 & 3.367 & 0.001 & $\mathrm{Y}$ \\
$\mathrm{H} 9$ & $\mathrm{SuC} \rightarrow \mathrm{ICT}$ & 0.030 & 0.332 & 0.740 & $\mathrm{~N}$ \\
$\mathrm{H} 10$ & $\mathrm{PK} \rightarrow \mathrm{ICT}$ & 0.046 & 0.471 & 0.638 & $\mathrm{~N}$ \\
$\mathrm{H} 11$ & $\mathrm{SuC} \rightarrow \mathrm{LI}$ & 0.061 & 0.819 & 0.413 & $\mathrm{~N}$ \\
\hline
\end{tabular}

\subsection{Findings}

\subsubsection{Significant Influence Factors}

(1) Previous market channels have a significant negative impact on BoPs' entrepreneurial intention in rural e-commerce. In comparison with existing literature, this particular variable has not been evaluated or considered in previous studies on e-commerce entrepreneurship. The rural market capacity is limited, and the traditional sales channels may encounter difficulties meeting agricultural production requirements [4]. The emergence of e-commerce has provided a more extensive and convenient channel for the sale of agricultural products [33,34]. Furthermore, BoPs can acquire cheaper items through rural e-commerce sites. Hence, rural e-commerce has overcome the issue of restricted market channels, and when it arrives in BoP communities, it is easily to attract the attention of the BoP population.

(2) Professional knowledge has a significant positive impact on BoPs' entrepreneurial intention in rural e-commerce. This result aligns with the findings of Liu [6], Gao and Liu [11], and Wan et al. [8]. Professional knowledge of e-commerce entrepreneurship can be learned in various ways (e.g., being taught by a local business leader, attending offline training classes, or learning online by themself). It is worth noting that the average BoP does not have the professional knowledge required to start a business [4]. They must study or imitate in order to gain competence. The more knowledge the $\mathrm{BoP}$ acquires, the more receptive they become to rural e-commerce entrepreneurship. As a result, professional knowledge is a critical component for BoPs who want to use rural e-commerce as a steppingstone to entrepreneurship. This might explain why professional knowledge could be a crucial element in this study. 
(3) The results also found a significant positive impact of resource endowment on BoPs' entrepreneurial intention in rural e-commerce, similar to the conclusions of Borch et al. [37] and Mei et al. [14]. The rich, mostly untapped resources among BoP communities provide the necessary industrial and material bases for e-commerce. For example, areas rich in fruit products can start a fruit e-commerce business. Different resource endowments provide diversified options for BoPs to become e-commerce entrepreneurs. If there are any rich resources in the BoP community, they can give product and industry support for BoPs to engage in rural e-commerce entrepreneurship. More significantly, compared to external resources, local resources will be easier to obtain and will be less expensive [36], allowing BoPs to maintain a competitive edge in the entrepreneurial process [37]. Therefore, resource endowment is favorable to encouraging BoPs' entrepreneurial intention in the context of the rapid expansion of rural e-commerce.

(4) ICT was also found to have a significant positive impact on BoPs' entrepreneurial intention in rural e-commerce, consistent with the finding of Zhou et al. [13], Zheng et al. [23], and Liu [6]. Advances in ICT make possible online sales that overcome the time and space limitations of the traditional mode of trading. Products can be marketed and sold to "distant" consumers through the internet. ICT is an indispensable factor that allows BoP entrepreneurs to engage in rural e-commerce [23]. ICT is critical in removing information asymmetry in the BoP market [6] and enabling real-time and varied online marketing [13]. The aforementioned considerations may explain why BoPs feel that ICT has a major beneficial influence on their entrepreneurial intention.

(5) Similar to the findings of Zhou and Liu [38], the results show that logistics infrastructure positively impacted BoPs' entrepreneurial intention in rural e-commerce. Traditionally, transportation in most BoP communities is inconvenient and underdeveloped, hindering local economic growth. As an essential part of e-commerce development, improvements in logistics infrastructure help make the delivery of goods more efficient and cost-effective. In reality, the local government has been focusing on logistics infrastructure building in our survey region in recent years. Jieyang, for example, established and implemented a strategy to support the growth of the express delivery logistics industry in 2017 [59], while Chaozhou announced a rural logistics development plan in 2019 [60]. The logistics infrastructure of the two locations has been substantially enhanced thanks to the combined efforts of local governments and businesses. These infrastructure improvements are crucial to stimulate, encourage, and support BoPs' entrepreneurial intention in e-commerce.

\subsubsection{Non-Significant Influence Factors}

(1) Previous income was found to have no significant impact on BoPs' entrepreneurial intention in rural e-commerce. This finding is contrary to the conclusions of Liu [6] and Bruton et al. [32]. This may be due to the fact that while BoPs are often low-income earners [4], they have a variety of options for increasing their income, including e-commerce entrepreneurship. For example, they can go out to work in cities or continue with traditional agricultural production. In addition, BoPs generally have limited knowledge, financial resources, and entrepreneurial skills [4]. Before starting an e-commerce business, BoPs would need to increase their professional knowledge and improve their entrepreneurial skills. Hence, previous income may play a significant role in BoPs' attempts to learn new skills and enhance their status. Overall, there are a variety of factors that may be utilized to replace previous income as a direct motivator. Previous income is not a necessary component of e-commerce practitioners' entrepreneurial intention.

(2) Start-up cost had no significant impact on BoPs' entrepreneurial intention. This result is similar to the findings of Liu [6] and Gao and Liu [11] but is contrary to those of Wan et al. [8]. One possible explanation is that although BoP start-ups involve some costs, such as buying computers, smartphones, and obtaining internet connection, these costs are generally low $[6,11]$ and are within the price range that most BoPs can afford. In addition, the installment payment method from various e-commerce platforms also supports BoPs 
in purchasing supplies and equipment. Therefore, the start-up cost is not a barrier to BoPs' entrepreneurial intention in rural e-commerce, which explains our paper's findings.

(3) The development prospect of rural e-commerce had no significant impact on BoPs' entrepreneurial intention in rural e-commerce, contrary to the conclusion of Chao et al. [1]. This might be because, while the prospects of e-commerce surge may attract enterprises to invest in rural communities [18], a BoP needs to be aware of the development trends in rural e-commerce and take appropriate measures. However, due to market information asymmetry, BoPs are often marginalized, making it difficult to recognize trends and opportunities when they first appear. In addition, while the vast majority of people realize that e-commerce has a promising future, some pioneering entrepreneurs are often ahead of the curve. Therefore, this factor is insignificant to the vast majority of BoP e-commerce practitioners.

(4) ICT was found to have no mediating effect on start-up costs and professional knowledge. This conclusion is contrary to the findings of Liu [6], Gao and Liu [11], and Zhou et al. [13]. One possible explanation is that while ICT can reduce start-up costs and improve professional knowledge, the impact on BoPs is largely implicit and is not easily perceivable. In other words, the BoP pays a certain amount of money to purchase the products and services related to the information and communication. These expenditures, however, are modest, and the BoP can afford them $[6,11]$.

(5) Logistics infrastructure had no mediating effect on start-up costs, contrary to the findings of Chen and $\mathrm{Yu}$ [9]. One possible explanation is that when BoPs start their e-commerce business, the local logistics infrastructure has already been established. If the logistics infrastructure is not fully operational or is underdeveloped, very few people would be able to start an e-commerce business. Given that the effects of logistics infrastructure on start-up costs are not as explicit, BoPs may have difficulty perceiving and acknowledging the connection.

\section{Discussion}

The results show that five of the eleven hypotheses were confirmed. Professional knowledge, resource endowment, information and communication technology, and logistics infrastructure were found to have significant positive correlations with BoPs' entrepreneurial intention in rural e-commerce. In comparison, the previous market channel was found to have a significant negative correlation, which suggests that the BoP's narrow market channels encourage e-commerce entrepreneurship in rural markets. These findings are largely consistent with those from previous studies.

However, some of the results differed from the findings of previous studies. We found that previous income, start-up costs, and the development prospect of rural e-commerce had no significant impact on BoPs' entrepreneurial intention. Additionally, ICT had no mediating effect on start-up costs and professional knowledge, and logistics infrastructure had no mediating effect on start-up costs. In the findings section, we evaluated the probable reasons for significant or non-significant factors based on the results. However, while we discovered evidence of probable ICT and logistics infrastructure mediation effects in the literature (e.g., evidence from Liu [6], Gao and Liu [11], Zhou et al. [13] for ICT; proofs from Chen and $\mathrm{Yu}$ [9] for logistics infrastructure), our empirical results were not significant. Even though we explored the possible explanations of the disparities in our study, we hope that future studies will be able to dig further into these discrepancies and investigate the circumstances that lead to them.

The following are the theoretical and practical implications based on the various research findings.

\subsection{Theoretical Implications}

First, this paper enriches the literature on BoPs' entrepreneurial intention in rural e-commerce. The majority of existing studies use the case analysis method (e.g., Liu [6]; Guo and Zhou [10]; Gao and Liu [11]; Zhou et al. [13]) to assess the mechanisms affecting 
entrepreneurship in the rural e-commerce market, and only a few have employed empirical analysis [14]. This paper empirically evaluates the various influencing factors in BoPs' rural e-commerce entrepreneurial intention, providing new perspectives on the subject.

Second, prior research has focused on the impact of feasibility factors on BoPs' entrepreneurial intention in rural e-commerce (e.g., Liu [6]; Gao and Liu [11]; Zhou et al. [13]; Mei et al. [14]), whereas desirability factors have received less attention. Our research looked at how previous market channels influenced BoP e-commerce and discovered a negative correlation. As a consequence, we were able to offer fresh perspectives on the subject.

Third, unlike previous studies that do not focus on people from low-income backgrounds, our study focuses on persons from poor contexts. The poorest in society have inadequate skills, knowledge, and financial resources [4]. As a consequence, while beginning a business, the BoPs evaluate not just general issues like cost [61], but also elements like skills and knowledge acquisition. Non-BoP practitioners, on the other hand, may already have extensive operational experience and working abilities, which are distinct from the professional knowledge factor considered in our study.

Finally, this study demonstrates that the entrepreneurial event model may be used to identify and investigate the factors that influence BoPs' entrepreneurial intention in rural e-commerce. This further expands the application of the entrepreneurial event model into other disciplines. In addition, we focus on how planned behavior theory can be used to analyze entrepreneurial intention [42] and how the opportunity-driven vs. necessity-driven entrepreneurship paradigm may be applied to individual entrepreneurial endeavors [62] The eight factors proposed in this study should be categorized based on distinct criteria and ideas, according to these two theories or models. Furthermore, under the study framework, factors such as family background, societal and financial status of entrepreneurs may be integrated and interpreted. All of them have significant theoretical implications for future entrepreneurial intention research. These can be utilized to guide our study in the next part of our project.

\subsection{Practical Implications}

Based on the results of the study, a number of practical recommendations are proposed in support of entrepreneurship among BoPs in e-commerce. First, BoPs should focus more on cultivating professional knowledge on e-commerce entrepreneurship. Our results showed a positive correlation between professional knowledge and BoP e-commerce entrepreneurship. To promote entrepreneurship and support the viability of doing ecommerce business in rural markets, BoPs should acquire more professional knowledge through training, formal and informal education, and other skills development platforms $[6,8,11]$. In addition, e-commerce platform enterprises or local governments (policymakers) could actively encourage and support rural e-commerce entrepreneurship by providing activities that would enhance professional knowledge among BoP.

Second, BoPs should capitalize on local characteristic resources in rural e-commerce. We found that resource endowment is positively correlated with BoP entrepreneurship. E-commerce can help provide marketing and logistical support for local agricultural and sideline products [1]. Resources (e.g., tourism resources and agricultural products resources) in rural regions that were otherwise untapped, underutilized, or undervalued could be better publicized and utilized by BoPs through e-commerce.

Third, e-commerce platform enterprises or local governments (policymakers) should pay attention to the construction and improvement of the ICT and logistics infrastructure, particularly in BoP communities. We found that ICT and logistics infrastructure are positively correlated with BoP entrepreneurship in rural e-commerce. BoP communities' infrastructure had been relatively backward and undeveloped, resulting in a variety of logistical and communication challenges [63]. E-commerce enterprises and policymakers should focus on building and improving ICT and logistics infrastructure in BoP communities to support and encourage BoPs' entrepreneurial intention in rural e-commerce. 
Finally, policymakers should foster an environment that encourages e-commerce entrepreneurship in BoP communities, and low-income people can try their hand at rural e-commerce. Previous market channels had a significant negative impact on BoPs' entrepreneurial intention in rural e-commerce, according to our findings. Rural e-commerce is a good choice for BoP to establish an enterprise, according to Liu [6], Guo and Zhou [10], Gao and Liu [11]. It can definitely increase farmers' earnings while also increasing the resilience of BoP communities. It is worth noting that rural e-commerce may offer a wide range of online sales channels, which can help to alleviate the problem of low agricultural product sales $[6,33]$.

\section{Conclusions}

BoP entrepreneurship in rural e-commerce is a viable way to alleviate poverty and promote sustainable social development. This is why understanding how to better encourage and support BoP to participate in rural e-commerce is extremely important. However, there are a number of challenges that hinder or discourage BoP from participating in e-commerce as entrepreneurs. If these issues are not addressed, BoP may only be limited to being a "consumer" or "partner" rather than being an independent "entrepreneur".

This study focuses on the building of theoretical models and the identification of influencing variables in order to better understand the factors influencing BoPs' entrepreneurial intention in rural e-commerce. More specifically, we built a study framework based on the entrepreneurial event model (desirability and feasibility aspects), conducted an online survey of rural e-commerce practitioners in Guangdong Province, China, and empirically evaluated the survey findings using SmartPLS software. Our empirical results show that professional knowledge, resource endowment, information and communication technology, and logistics infrastructure have a significant positive impact, while previous marketing channels have a significant negative impact. Our research results contribute to the existing knowledge on rural e-commerce entrepreneurship, and they can assist BoPs in identifying favorable socio-economic factors and facilitating their transition to rural e-commerce entrepreneurship growth.

Based on the findings of this study, we recommend that BoPs should focus on cultivating professional knowledge in e-commerce and capitalizing on local resources. Meanwhile, BoPs can experiment with rural e-commerce as a means of entrepreneurship. E-commerce platform enterprises and local governments should construct and improve ICT and logistics infrastructure for BoP communities. Policymakers should foster an environment that encourages e-commerce entrepreneurship in low-income neighborhoods. These recommendations would help create a favorable environment that would encourage BoPs to become e-commerce entrepreneurs and promote local capacity-building.

This paper has several research limitations. First, our survey data came from two BoP communities in Guangdong Province, China. In different geographical environments, the factors that affect BoPs' entrepreneurial intention in rural e-commerce may vary. Future studies can explore more on the regional factors that could affect the results. Moreover, due to the pandemic, our questionnaire survey was only carried out online, and the effective samples obtained were relatively small (172). As a result of the regional breadth and sample size limitations, our conclusions and recommendations are tentative and suggestive rather than solid and definitive. To put it another way, they are insightful and intelligent conclusions and proposals, and we need to tailor the BoP entrepreneurship strategy to the circumstances of other areas. Third, in different theoretical research backgrounds, more diverse influencing factors may need to be considered. For example, future studies can analyze the effects of patrimonial culture in BoP communities, the education level of the BoP individuals, societal and financial status of entrepreneurs and family member recognition on e-commerce entrepreneurship. Fourth, our results are limited to the discussion of possible influencing factors for the current period. As time passes, the environment of BoP communities may change, which may modify the effects of different variables and generate new factors. These temporal changes could be explored in future studies. Finally, BoP 
entrepreneurship in rural e-commerce is an emerging research topic, and the evaluation of influencing factors is only one aspect. The specific effects and risks of BoP entrepreneurship in the e-commerce market, as well as the application and challenges of new technologies (such as short video and live broadcast), can be studied in future works.

Author Contributions: Conceptualization, G.X. and L.H.; methodology, G.X.; software, G.X.; validation, G.X., L.H. and W.C.; formal analysis, G.X.; investigation, G.X. and L.H.; resources, L.H.; data curation, G.X. and L.H.; writing —original draft preparation, G.X.; writing—review and editing, G.X., R.H., G.L. and C.A.; visualization, G.X. and W.C.; supervision, L.H.; project administration, L.H.; funding acquisition, L.H. All authors have read and agreed to the published version of the manuscript.

Funding: This research was funded by the NATIONAL SOCIAL SCIENCE FOUNDATION OF CHINA, grant number 21BGL032, and 19BGL177; 2021 GUANGDONG PROVINCE'S COLLEGES AND UNIVERSITIES' TYPICAL INNOVATION PROJECTS, grant number 2021WTSCX070.

Informed Consent Statement: Informed consent was obtained from all subjects involved in the study.

Data Availability Statement: If necessary, we would be pleased to share the research data in this work with interested academics. We also intend to have a more in-depth discussion with academics about how SmartPLS works. Please contact the second author by email (1111965003@e.gzhu.edu.cn) if you have any data requests. I'm excited to meet additional specialists and academics in the same field.

Acknowledgments: The authors thank the editor and anonymous reviewers for their numerous constructive comments and encouragement that have improved our paper greatly. We are also grateful for the support of 2019 Guangdong Provincial Higher Education Teaching Reform Project (project title: exploration and practice of cross-border e-commerce talent training mode in universities under the initiative of "One Belt, One Road"), and the Comprehensive Educational Reform Project of E-commerce Major Teaching Steering Committee of Guangdong Undergraduate Universities (project title: mode and practice exploration of rural e-commerce innovation and entrepreneurship talent cultivation in the era of digital economy).

Conflicts of Interest: The authors declare no conflict of interest.

\section{Appendix A}

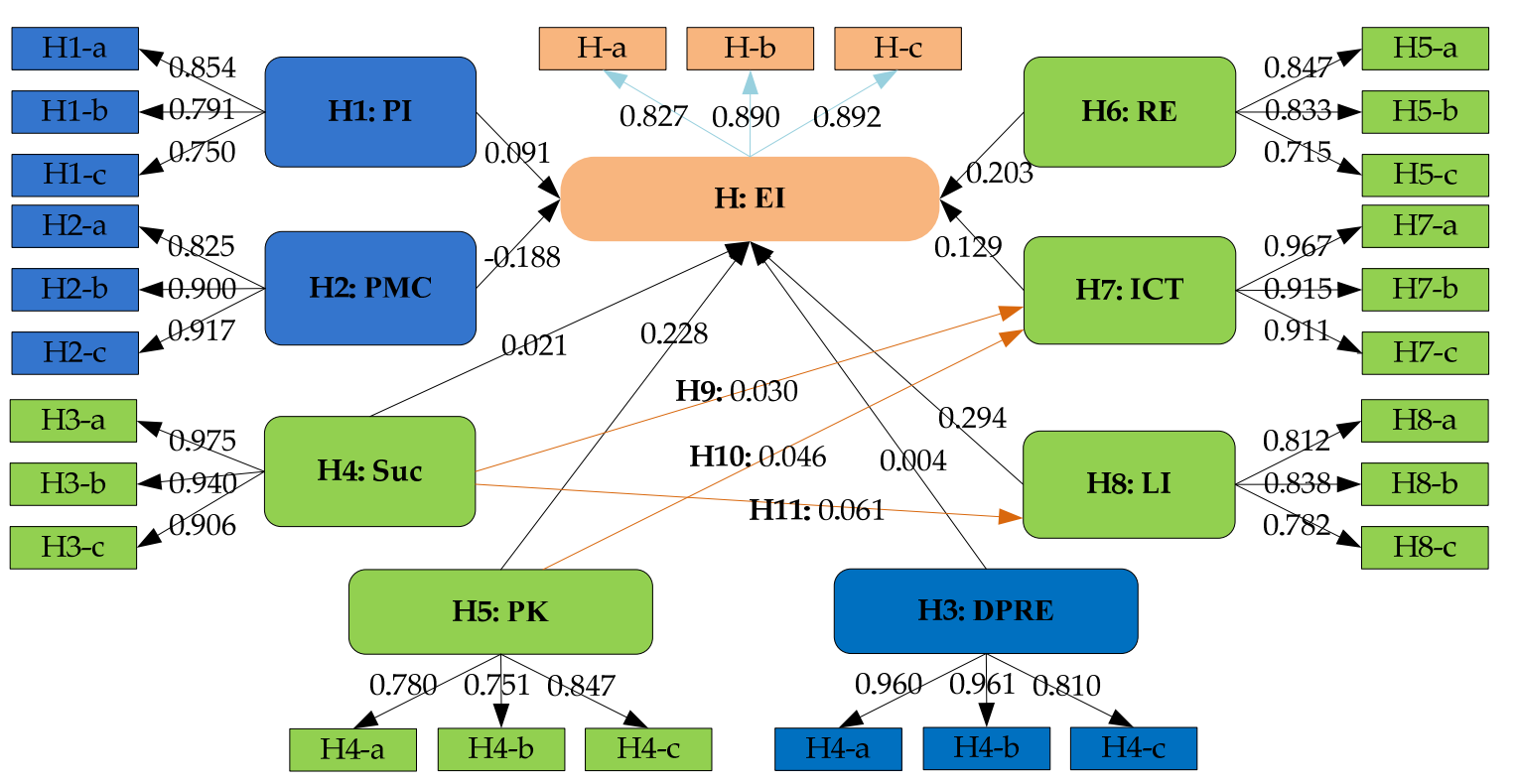

Figure A1. The model results. 


\section{References}

1. Chao, P.; Biao, B.; Chen, Z.C. Poverty Alleviation through E-Commerce: Village Involvement and Demonstration Policies in Rural China. J. Integr. Agric. 2021, 20, 998-1011.

2. China Internet Network Information Center. The 47th Statistical Report on Internet Development in China. Available online: http: / / www.cac.gov.cn/2021-02/03/c_1613923422728645.htm (accessed on 10 June 2021).

3. Ministry of Commerce, PRC. The Person in Charge of the e-Commerce Department of the Ministry of Commerce Talks about the Development of the Online Retail Market in 2020. Available online: http:/ / www.mofcom.gov.cn/article/news/202101/2021010 3033238.shtml (accessed on 10 June 2021).

4. Prahalad, C.K. Bottom of the Pyramid as a Source of Breakthrough Innovations. J. Prod. Innov. Manag. 2012, 29, 6-12. [CrossRef]

5. Lappeman, J.; Ransome, K.; Louw, Z. Not one Segment: Using Global and Local BoP Characteristics to Model Country-Specific Consumer Profiles. Eur. Bus. Rev. 2019, 31, 317-336. [CrossRef]

6. Liu, Y.J. Double-Case Study on Endogenous Inclusive Growth Promoted by Internet Enabling and Bottom-of-the-Pyramid Entrepreneurship. Chin. J. Manag. 2018, 15, 28-38.

7. Campos, A.C.; Rezende, D.; Prado, J.; do Nascimento, T.B.P.; Grutzmann, A. Consumption at the Bottom of the Pyramid: Current State of Research and Suggestions for Future Study. EMAJ Emerg. Mark. J. 2020, 10, 40-49. [CrossRef]

8. Wan, Q.W.; Wei, T.; Liu, J. Bridging Social Capital: Building a Dyadic Relationship between Corporate Social Entrepreneurs and Local Individuals at the Bottom of the Pyramid: A Single Case Study of Rural E-Commerce Project of LZ.com. Manag. World 2019, 35, 179-196.

9. Chen, X.T.; Yu, G.X. The Shaping and Reconstruction of Rural Community Booted by Rural E-Commerce-An Empirical Analysis Based on Suichang County of Zhejiang Province. Probe 2019, 5, 132-140.

10. Guo, Y.L.; Zhou, Y.F. From Exogenous Assistance to Endogenous Driving: A Case Study of Minority BoP Inclusive Innovation. Manag. World 2021, 37, 159-180.

11. Gao, P.; Liu, Y. Endogenous Inclusive Development of E-commerce in Rural China: A case study. Growth Chang. 2020, 551, 1611-1630. [CrossRef]

12. Steiner, A.; Atterton, J. Exploring the Contribution of Rural Enterprises to Local Resilience. J. Rural Stud. 2015, 40, 30-45. [CrossRef]

13. Zhou, J.; Yu, L.; Choguill, C.L. Co-evolution of Technology and Rural Society: The Blossoming of Taobao Villages in the Information Era, China. J. Rural Stud. 2021, 83, 81-87. [CrossRef]

14. Mei., Y.; Mao, D.; Lu, Y.; Chu, W. Effects and Mechanisms of Rural E-commerce Clusters on Households' Entrepreneurship Behavior in China. Growth Chang. 2020, 51, 1588-1610. [CrossRef]

15. López-Morales, J.S.; Rosario-Flores, F.; Huerta-Estevez, A. Business in the Base of the Pyramid: A Literature Review and Directions for Future Research. Organ. Mark. Emerg. Econ. 2020, 11, 327-347.

16. Gardetti, M. A Base-of-the-Pyramid Approach in Argentina: Preliminary Findings from a BoP Learning Lab. Greener Manag. Int. 2005, 51, 65-77. [CrossRef]

17. Cañeque, F.C.; Hart, S. Base of the Pyramid 3.0: Sustainable Development through Innovation and Entrepreneurship; Greenleaf Publishing: Sheffield, UK, 2015.

18. Sousa, R.; Horta, C.; Ribeiro, R.; Rabinovich, E. How to Serve Online Consumers in Rural Markets: Evidence-based Recommendations. Bus. Horiz. 2020, 63, 351-362. [CrossRef]

19. Cooney, K.; Williams Shanks, T.R. New Approaches to Old Problems: Market-based Strategies for Poverty Alleviation. Soc. Serv. Rev. 2010, 84, 29-55. [CrossRef]

20. Xing, X.Q.; Ge, H.F.; Tong, Y.H. Social Embeddedness and Evolution of BOP Networks: A Longitudinal Case Study. Manag. World 2015, 10, 160-173.

21. Clarke, G.; Thompson, C.; Birkin, M. The Emerging Geography of E-commerce in British Retailing. Reg. Stud. Reg. Sci. 2015, 2, 371-391. [CrossRef]

22. Ma, Y.N.; Wang, X.Q.; Zhao, A.Q.; Jiang, Z.R. A Case Study of Crowdfunding for Packaging to Improve the Packaging Ability of Fresh Fruit in Rural E-commerce. Shanxi Agric. Econ. 2017, 5, 132-134.

23. Zheng, G.; Chen, X.; Si, X.F. Alleviate Poverty through the Internet and inclusive Entrepreneurship: Case of Dongfeng Village. Stud. Sci. Sci. 2020, 38, 1818-1827, 1887.

24. Liang, Q.; Zou, L.K.; Yang, X.R.; Kong, B. Research on Mechanism of Government Support on Inclusive Entrepreneurship: Case study of Jieyang Junpu Rural E-commerce Entrepreneurial Cluster. South China J. Econ. 2016, 1, 42-56.

25. Graebner, E. Theory Building From Cases: Opportunities and Challenges. Acad. Manag. J. 2007, 50, $25-32$.

26. Shapero, A.; Sokol, L. The Social Dimensions of Entrepreneurship. University of Illinois at Urbana-Champaign's Academy for Entrepreneurial Leadership Historical Research Reference in Entrepreneurship, 1982. Available online: https://ssrn.com/ abstract $=1497759$ (accessed on 10 June 2021).

27. Krueger, N. The impact of prior entrepreneurial exposure on perceptions of new venture feasibility and desirability. Entrep. Theory Pract. 1993, 18, 5-21. [CrossRef]

28. Soomro, B.A.; Lakhan, G.R.; Mangi, S.; Shah, N. Predicting entrepreneurial intention among business students of public sector universities of Pakistan: An application of the entrepreneurial event model. World J. Entrep. Manag. Sustain. Dev. 2020, 16, 219-230. [CrossRef] 
29. Ali, B.; Shah, N.; Anwar, S. Investigating entrepreneurial intention through entrepreneurial event model (EEM) among graduate and master students in public sector universities of Thailand. Asia Pac.-Annu. Res. J. Far East South East Asia 2019, 34, 36-53.

30. Karnani, A. Romanticising the Poor Harms the Poor. J. Int. Dev. 2009, 21, 76-86. [CrossRef]

31. Xing, X.Q.; Tong, Y.H.; Chen, X.P. Business Models at the Bottom of the Pyramid: A Multi-case Study. Manag. World 2011, 10, $108-124$.

32. Bruton, G.D.; Ketchen, D.J.; Ireland, R.D. Entrepreneurship as a Solution to Poverty. J. Bus. Ventur. 2013, 28, 683-689. [CrossRef]

33. Wang, C.A.; Jtm, B.; Nap, B.; Zhang, J. E-commerce and the Transformation of the Rural: The Taobao Village Phenomenon in Zhejiang Province, China-ScienceDirect. J. Rural Stud. 2021, 81, 159-169. [CrossRef]

34. Agricultural Industry Observation. Alibaba Jingdong Pinduoduo to Promote the Development of Rural E-Commerce; Project Recommendation: Jingdong Plant Factory. Available online: https:/ / baijiahao.baidu.com/s?id=1627431412740620971\&wfr= spider\&for $=p c$ (accessed on 12 June 2021).

35. Ministry of Commerce of the People's Republic of China. The Annual Transaction Volume of Rural E-Commerce in China has Exceeded One Trillion Yuan. Available online: http://www.mofcom.gov.cn/article/i/jyjl/j/202012/20201203023299.shtml (accessed on 12 June 2021).

36. Müller, S.; Korsgaard, S. Resources and Bridging: The role of Spatial Context in Rural Entrepreneurship. Entrep. Reg. Dev. 2018, 30, 224-255. [CrossRef]

37. Borch, O.J.; Førde, A.; Rønning, L.; Vestrum, I.K.; Alsos, G.A. Resource Configuration and Creative Practices of Community Entrepreneurs. J. Enterprising Communities People Places Glob. Econ. 2008, 2, 100-123. [CrossRef]

38. Zhou, Y.H.; Liu, C.Y. Analysis on the Aggregation of Farmers' E-commerce and Influencing Factors in "China's Taobao Villages": A Survey of Shaji Town and Yanji Town in Jiangsu Province. South China J. Econ. 2018, 37, 62-84.

39. Zhang, C.; Zhang, G.S.; Wang, Y.L. Co-evolution and Policy Optimization of Rural E-commerce and Rural Logistics under Government Poverty Alleviation. J. Beijing Jiaotong Univ. 2020, 19, 98-105.

40. Adelson, J.L.; Mccoach, D.B. Measuring the Mathematical Attitudes of Elementary Students: The Effects of a 4-Point or 5-Point Likert-Type Scale. Educ. Psychol. Meas. 2010, 70, 796-807. [CrossRef]

41. Huang, L.J.; Xie, G.J.; Blenkinsopp, J.; Huang, R.; Bin, H. Crowdsourcing for Sustainable Urban Logistics: Exploring the Factors Influencing Crowd Workers' Participative Behavior. Sustainability 2020, 12, 3091. [CrossRef]

42. Kautonen, T.; Marco, V.G.; Matthias, F. Robustness of the theory of planned behavior in predicting entrepreneurial intentions and actions. Entrep. Theory Pract. 2015, 39, 655-674. [CrossRef]

43. Chen, L.P. Build the Development Pole of the less Developed Coastal Areas in Eastern Guangdong. Learn. Res. $2013,1,53$.

44. Guangdong Poverty Alleviation Information Network. List and Contact Information of 2277 Relative Poor Villages in the Province. Available online: http:/ / www.gdfp.gov.cn/tzgg/gsgg/201706/t20170626_848350.htm (accessed on 13 June 2021).

45. Hi Business School. What is Taobao Village and Taobao Town to Maintain a Standard? Available online: https://www.hishop. com.cn/wztb/show_90383.html (accessed on 13 June 2021).

46. Net social. Alibaba Research Institute: 2020 China Taobao Village Research Report. Available online: http://www.100ec.cn/ detail--6573965.html (accessed on 13 June 2021).

47. Daily Express. Taobao Village 2020 National Top 100 List. Available online: http:/ / www.ttpaihang.com/news/daynews/2020/2 0102752627.htm (accessed on 13 June 2021).

48. Jieyang Poverty Alleviation Information Network. Announcement on the Withdrawal of Jieyang's Relatively Poor Villages in 2019. Available online: http:/ / www.jieyang.gov.cn/fpb/xxgk/tpcxjkhxx/content/post_405518.html (accessed on 13 June 2021).

49. Chaozhou Municipal People's Government. Chaozhou Plans to Withdraw from the Public Notice of 45 Provinces Designated as Relatively Poor Villages. Available online: http:/ /www.chaozhou.gov.cn/zwgk/snxx/content/post_3660091.html (accessed on 13 June 2021).

50. Guangdong Province Electronic Commerce Integrated Information Platform. Nine Counties in Guangdong were Selected as the 2019 National Comprehensive Demonstration Counties for E-commerce in Rural Areas. Available online: https://www.gd-eca. org.cn/newsinfo/2112339.html (accessed on 13 June 2021).

51. Gefen, D.; Rigdon, E.E.; Straub, D. An Update and Extension to SEM Guidelines for Administrative and Social Science Research. MIS Q. 2011, 35, iii-xiv. [CrossRef]

52. Sarstedt, M.; Ringle, C.M.; Hair, J.F. Partial Least Squares Structural Equation Modeling; Springer International Publishing: Manhattan, NY, USA, 2017.

53. Xie, G.J.; Huang, L.J.; Apostolidis, C.; Huang, Z.; Cai, W.; Li, G. Assessing Consumer Preference for Overpackaging Solutions in E-Commerce. Int. J. Environ. Res. Public Health 2021, 18, 7951. [CrossRef] [PubMed]

54. Munerah, S.; Koay, K.Y.; Thambiah, S. Factors Influencing Non-green Consumers' Purchase Intention: A Partial Least Squares Structural Equation Modelling (PLS-SEM) Approach. J. Clean. Prod. 2021, 280, 124192. [CrossRef]

55. Boubker, O.; Arroud, M.; Ouajdouni, A. Entrepreneurship Education Versus Management Students' Entrepreneurial Intentions. A PLS-SEM Approach. Int. J. Manag. Educ. 2021, 19, 100450. [CrossRef]

56. Sarstedt, M.; Cheah, J.H. Partial Least Squares Structural Equation Modeling using SmartPLS: A Software Review. J. Mark. Anal. 2019, 7, 196-202. [CrossRef]

57. Sharma, R.; Yetton, P.; Crawford, J. Estimating the Effect of Common Method Variance: The Method-Method Pair Technique with an Illustration from TAM Research. MIS Quart 2009, 33, 473-490. [CrossRef] 
58. Zhou, H.; Long, L.R. Statistical Remedies for Common Method Biases. Adv. Psychol. Sci. 2004, 12, 942.

59. Jieyang Municipal People's Government. Jieyang to Promote Express Logistics Industry Development Program. Available online: http:/ / www.jieyang.gov.cn/zwgk/jcxxgk/zfgb/2017n/jysrmzfgb2017ndeq/szfbgswj/content/post_356520.html (accessed on 14 August 2021).

60. Sohu Net. Chaozhou Municipal Government Held the 20th Executive Meeting of 2019 to Study the Construction of Rural Logistics Network and Other Matters. Available online: https://www.sohu.com/a/361392380_12021418459 (accessed on 14 August 2021).

61. Fonseca, R.; Lopez-Garcia, P.; Pissarides, C.A. Entrepreneurship, start-up costs and employment. Eur. Econ. Rev. 2001, 45, 692-705. [CrossRef]

62. Amorós, J.E.; Ciravegna, L.; Mandakovic, V.; Stenholm, P. Necessity or opportunity? The effects of state fragility and economic development on entrepreneurial efforts. Entrep. Theory Pract. 2019, 43, 725-750. [CrossRef]

63. Korsgaard, S.; Müller, S.; Tanvig, H.W. Rural entrepreneurship or entrepreneurship in the rural-Between place and space. Int. J. Entrep. Behav. Res. 2015, 21, 5-26. [CrossRef] 